This paper appeared as:

Jean-Christophe Verstraete, Sarah D'Hertefelt \& An Van linden. 2012. A typology of complement insubordination in Dutch. Studies in Language 36: 123-153.

\begin{abstract}
:
This paper presents an analysis of complement insubordination in Dutch, i.e structures that are formally marked as subordinate complement clauses but conventionally used as main clauses. We develop a typology of seven distinct construction types (in three semantic domains), none of which have been analysed in detail before. From a more general perspective, we show that insubordinate constructions provide a fresh perspective on the analysis of modality and evaluation, with semantic parameters that are not found in more typical exponents like modal verbs. In addition, we show that it is difficult to develop a schematic generalization over the different construction types, in spite of their apparent formal similarity as complement structures. We argue that this points to separate developmental trajectories for the different types, with a point of origin in different main-subordinate constructions, and different degrees of conventionalization for the resulting insubordinate constructions.
\end{abstract}

\title{
Keywords:
}

Insubordination, modality, evaluation, constructions, Dutch 


\section{A typology of complement insubordination in Dutch}

\section{$\underline{\text { 1. Introduction }}^{1}$}

This paper analyses a set of constructions in Dutch that are formally marked as subordinate, but conventionally used as main clauses, a phenomenon for which Evans (2007, see also 1993) has coined the more general term 'insubordination'. We will focus on complement clauses introduced by the general subordinator dat 'that', and we will propose a semantic typology of seven distinct types of complement insubordination (in three semantic domains), none of which have been studied in detail before. We will also bring out more general implications of our analysis, for the semantic domains of modality and evaluation, and for the nature and origins of insubordinate constructions more generally. From a semantic perspective, we will show that insubordinate constructions are interesting for the analysis of modality and evaluation, because they bring to the surface a range of parameters that are not found in more typical grammatical exponents like modal verbs and mood markers. From a constructional perspective, we will show that it is difficult to come up with a clear constructional generalization over the different types of complement insubordination, which suggests an erratic developmental trajectory, with separate paths and varying degrees of conventionalization for each type.

\footnotetext{
${ }^{1}$ Work on this paper was supported by project GOA/12/007, funded by the research council of the University of Leuven. Author contributions are as follows: SD did a first analysis of corpus data together with JCV, which resulted in the typology reported in D'Hertefelt (2010). JCV subsequently did further corpus work, developed a new analysis and typology, and wrote the text. AVL contributed to data and analysis. We are grateful to Svenja Kranich, Viktor Becher and other members of SFB 538 at the University of Hamburg for discussion of insubordination in German and Dutch, to Bill McGregor for comments on a related presentation, and to Ad Foolen, Ronny Boogaart, two anonymous reviewers and Ekkehard König for very detailed and useful comments on an earlier draft.
} 
The phenomenon of insubordination in Dutch is illustrated by the complement and conditional structures in (1a) and (1b). On the one hand, these structures have the typical characteristics of subordination in Dutch: they are introduced by subordinating conjunctions dat ('that') in (1a) and als ('if') in (1b) - and their finite verb is in the clause-final position used for subordinate clauses, rather than in the clause-second position used for main clauses. On the other hand, the conventional function of these constructions is not as a subordinate clause dependent on some main clause, but as a main clause, with its own illocutionary force. Thus, the complement structure in (1a) serves as piece of advice to the addressee, ${ }^{2}$ and the conditional structure in (1b) serves as a polite request to the addressee.

(1) a. Dat hij misschien eens in zijn achterzak kijkt. (IC) ${ }^{3}$ CONJ he perhaps PART in his back.pocket look.PRS ${ }^{4}$ 'He could try and check his back pocket.'

b. Als je hier even je handtekening wilt zetten. (IC) CONJ you here PART your signature want.PRS put 'If you could sign here.'

The phenomenon of insubordination is under-documented for most languages, even well-studied ones like Germanic or Romance languages, but as pointed out by Evans (2007,

\footnotetext{
${ }^{2}$ The term 'addressee' is used here to refer to the participant to whom a deontic judgement or general evaluation applies, regardless of whether this is the interlocutor, as in (1b), or a third person, as in (1a).

${ }^{3}$ Sources of examples are marked with the abbreviations CGN (Corpus Gesproken Nederlands), IC (own corpus of internet material), and C (constructed examples). ${ }^{4}$ Since the target language and the metalanguage are closely related, we decided on 'light' glossing to facilitate comprehension. We avoid morphological breakdown and use of category labels, except when they are relevant to the constructions examined here (e.g. to mark the position of the finite verb), or when no equivalent is available in the target language (e.g. for most particles). Abbreviations not in the Leipzig Glossing Rules are: CONJ conjunction, MOD modal, and PART particle.
} 
2009) it has very interesting theoretical implications. From a morphosyntactic perspective, insubordination looks strange because it goes against attested patterns of change between main and subordinate structures. Work on grammaticalization in this domain (e.g. Hopper \& Traugott 2003: 184-203) has shown how subordinate clauses typically develop from main clause structures, with conjunctions developing from deictic sources (like complementizers from demonstratives, e.g. Traugott 1992), or mood markers becoming distributionally restricted to subordinate contexts (as happened with subjunctive-like mood in some languages, e.g. Palmer 2001: 107). Insubordination shows exactly the opposite pattern, with a main clause structure developing from what is originally a subordinate construction, probably via a process of ellipsis of the main clause in a complex construction (Evans 2007), as illustrated in (2). This type of development goes against general claims about the 'unidirectionality' of grammaticalization processes, and provides even stronger evidence against unidirectionality in this domain than the subordinate-to-coordinate shifts that have been noted in the literature (e.g. Hopper \& Traugott 2003: 209-211, Verstraete 2005a).

(2) [Ik zou suggereren] (C, based on IC)

I would suggest

dat hij misschien eens in zijn achterzak kijkt. CONJ he perhaps PART in his back.pocket look.PRS Main-subordinate: 'I would suggest he check his back pocket.' Insubordinate: "He could try and check his back pocket.'

A second area to which insubordination is relevant is the interface between syntax and pragmatics. As argued by Evans (2007: 393), pragmatic considerations appear to play an important role in the development of these constructions. Thus, for instance, the need to put 
face-threatening aspects of an utterance 'off the record' is what may have led to the ellipsis of a main clause that refers explicitly to the speaker's own desires, as shown in (3). Such pragmatic considerations can leave their mark on the semantics of the insubordinate construction, in a process of conventionalization. This is illustrated, for instance, by the fact that insubordinate constructions like (1b) only allow the reconstruction of main clauses which signal or imply some kind of positive evaluation by the speaker (Evans 2007: 372-373), as shown in (3a) and (3b) below.

(3) Als je even kan langskomen

CONJ you PART can.PRS visit

a. zou me dat goed uitkomen.

would me DEM well suit

b. ?zou ik dat vervelend vinden]

would I DEM awkward find

'If you could come by [that would suit me well / ?that would be awkward].'

A final domain for which insubordination is relevant is the semantic analysis of 'interpersonal' categories, i.e. grammatical categories that deal with the negotiation of action, attitudes and information between speaker and interlocutor (see Halliday 1970, Verstraete 2007: 7-94). Such categories have traditionally been studied by looking at their most visible grammatical exponents, in systems of modality, evidentiality, mood or information structure. The meanings of insubordinate constructions are often situated in precisely these domains (Evans 2007, 2009), but they have barely been taken into account in semantic analyses. The two constructions in (1), for instance, both belong to the broad deontic domain, which deals with the negotiation of action. Traditionally, semantic analyses of this domain have been 
based on exponents like modal verbs, modal particles or imperative mood, leading to typologies based on the degree of desirability of the action, the polarity of the structure, or the directive use of the deontic expression (see Nuyts 2005 for an overview). Constructions like (1), by contrast, can bring to the surface features that are less obvious or even absent in more typical exponents. For instance, the construction in (1a) does not merely present a state of affairs as desirable for both the speaker and the addressee (as with weak modal verbs), but also suggests that this solution is obvious but not known to the addressee, an epistemic-type feature that is less clearly present in modal verbs or moods in Dutch.

The focus of this paper will be on the semantic and the constructional analysis of insubordinate complement constructions in Dutch, mainly Flemish varieties of Dutch, which have the broadest structural range of complement insubordination (Netherlandic Dutch varieties often have conditional insubordinate equivalents, as shown in De Rooij 1965.) We will analyse the semantic range of complement insubordination, paying attention to the different semantic categories, and we will investigate the formal, often idiosyncratic, features that define these categories as distinct construction types (i.e. form-meaning pairings in the sense of Goldberg 1995). Although Dutch is very well-described in general, insubordination has barely been touched upon in the literature, apart from one recent survey in Boogaart (2011), and a number of studies that mention problematic 'subordinate' types or emotionrelated constructions (e.g. the optative type to be discussed in section 2.1 and the evaluative type to be discussed in section 3, in De Rooij 1965: 117-121, van der Horst 1984: 114, Haeseryn et al. 1997: 23.5.2.2, Boogaart 2010, Foolen 2012). This is all the more surprising given that the phenomenon is extremely widespread in the language, especially in informal spoken varieties. Complement and conditional structures alone, for instance, yield more than fifteen different construction types, two of which were illustrated in (1). In addition, Dutch shows insubordination of various other types of finite and non-finite structures, like 
comparative clauses with alsof 'as if', complement clauses with interrogative complementizers, or infinitive clauses, illustrated in (4) below.

(4) a. Alsof wij niet zouden weten

CONJ we NEG would know

hoe we een begroting moeten maken.

how we ART budget must.PRS make

'Do you think we don't know how to make a budget?'

b. Waar ze toch allemaal tijd in steken.

CONJ they PART all time in put.PRS

'Why do they spend time on these things?'

c. Zo dichtbij te zijn geweest!

(Boogaart 2010: 9)

PART close to be.INF be.PTCP

'And we were so close!'

Within this broad range, we will focus on one specific category, viz. complement constructions introduced by the complementizer dat, like (1a) above. This is one of the most basic types of subordinators in the language (in terms of age, distribution and frequency), which at the same time offers the widest range of insubordinate constructions, rivalled only by the conditional conjunction als. Our analysis will distinguish between three broad categories of complement insubordination, which will be elaborated in a more fine-grained typology of seven construction types in the rest of this paper. The first category is deontic insubordination, which encodes some aspect of the speaker's hopes or desires about a potential state of affairs. ${ }^{5}$

\footnotetext{
${ }^{5}$ We will use the term 'state of affairs' (SoA) to refer to anything that can be the case, regardless of its internal semantic structure. Specific aspects of semantic structure will be
} 
The structure in (1a) illustrates one subtype, which encodes the speaker's suggestion about what the addressee should do. Another subtype is exemplified in (5), which encodes the speaker's wish or hope that someone will not be seasick.

(5) Dat hij maar niet zeeziek wordt.

CONJ he PART NEG seasick become.PRS

'I hope he doesn't get seasick.'

The second category is evaluative insubordination, which is not about the speaker's hopes or desires for a potential SoA, but their evaluation of an actual SoA, often but not necessarily current or past. This is exemplified in (6), where the speaker expresses their surprise or annoyance at what the interlocutor has just said.

(6) Dat gij dat durft te vertellen zoiets.

(CGN)

CONJ you DEM dare.PRS to tell such.thing

'I can't believe you dare to tell people something like that.'

The final category is discursive insubordination, where modal or evaluative factors do not play a role at all. Instead, the insubordinate construction serves to expand on an aspect of what they or their interlocutor have just said. An example is (7), where the speaker expands on their first turn to clarify what they mean with their question about a scanner.

(7) A: Heb je zelf wel 'ns een scan gehad?

(CGN)

B: Nee

referred to with terms like action, state or process, which will be used in their classic Aktionsart senses. 
A: Dat je in zo'n apparaat gaat.

CONJ you in such.a machine go.PRS

'A: Have you ever had a scan yourself? B: No. A: That's when you go into a machine like that.'

In the rest of this paper, we will further substantiate this basic subdivision, and we will show that there is a more fine-grained typology of construction types within each category. We will use data from spoken or semi-spoken corpora, specifically the Spoken Dutch corpus (Corpus Gesproken Nederlands, marked with CGN) and a collection of Dutch internet material (marked with IC). Constructed examples will be marked as such (using the abbreviation C). As already mentioned, some constructions are specific to Flemish varieties of Dutch, which means that our analysis at some points will be restricted to these varieties. We will not go into regional variation any further - which is a topic in its own right - except to note occasionally when Netherlandic Dutch uses insubordinate alternatives of the conditional type. For each construction type, we will provide a semantic and formal analysis, leading to a typology of seven distinct constructions.

In section 2, we will focus on the largest category, deontic insubordination. We will show that the different deontic types can be distinguished on the basis of parameters like the addressee's control over the SoA, the relation between the speaker's and the addressee's attitudes, and the typical polarity of the construction. In section 3, we will focus on evaluative insubordination, showing that subtypes can be distinguished on the basis of parameters like the expectedness of the event being evaluated, and the positive or negative nature of the evaluation involved. In section 4, we will describe discursive insubordination and the discourse function it fulfills, specifically expansion and explanation. In section 5, finally, we will bring all constructions together in a more general typology, showing that in spite of their 
general formal similarity, it is difficult to derive an overall constructional schema that covers all of them. Similarly, we will show that each of these units has a different relation to their subordinate counterparts, which suggests an erratic developmental trajectory from subordination to insubordination, with varying degrees of conventionalization.

\section{Deontic insubordination}

Deontic types of insubordination deal with the desirability of a potential SoA. For instance, the structures in (8) and (9) below express the speaker's desire that the addressee recovers soon and that the addressee should not have low expectations, respectively.

(8) Dat ze maar gauw volledig genezen is.

CONJ she PART quickly fully heal.PTCP be.PRS

'I hope she recovers fully soon.'

(9) Dat je maar niet denkt dat het allemaal oude koek is. (IC) CONJ you PART NEG think.PRS CONJ it all old biscuit be.PRS 'Just don't think it's all old hat.'

Within this broad category, a basic distinction can be made depending on whether the addressee has control over the realization of the SoA, and the speaker intervenes in its realization. Uncontrolled types like (8) present the addressee as not having any control over the realization of the SoA. Accordingly, the speaker does not intervene in its realization but merely expresses commitment to its desirability. These types will be discussed in more detail in section 2.1. In controlled types like (9), by contrast, the addressee is presented as having control over the realization of the SoA, and the speaker intervenes in its realization, in this 
case by ordering the addressee not to think in a particular way. These types will be discussed in more detail in section 2.2. This is a broad conception of deontic modality, bringing together both the expression of desirability and the domain of directive speech acts, which some have argued should be kept separate (Kiefer 1997, Nuyts et al. 2010, Van linden \& Verstraete 2011). In this context, we have chosen this broad conception to bring out the semantic commonalities between structures like (8) and (9), in contrast with the evaluative and discursive types of insubordination to be discussed in sections 3 and 4 below.

\subsection{Uncontrolled deontic insubordination}

Uncontrolled deontic insubordination covers the traditional 'optative' category of hopes and wishes: the speaker expresses their commitment to the desirability of a particular SoA beyond the control of the addressee (if there is one), but does not intervene in its realization. Thus, for instance, in (10) below, the speaker expresses their desire that the addressees may live long and happily together, and in (11) that the end of the week should come quickly. In both cases the SoA is represented as beyond the control of the speaker and the addressees. In fact, the lexical meaning of the verbs used in these constructions often lacks a feature of control (e.g. leven 'live' in (10) and zijn 'be' in (11)), although as we will see below controlled activities are not excluded but coerced into an uncontrolled reading.

(10) Dat ze nog lang en gelukkig samen mogen leven! CONJ they PART long and happily together may.PRS live 'I wish them a long and happy life together.'

(11) Dat het maar rap vrijdag is!

CONJ it PART quickly Friday be.PRS 
'I wish it were Friday!'

Unlike controlled deontic types of insubordination, the uncontrolled types discussed here do not have clear grammaticalized counterparts in the Dutch system of mood and modality: there is no optative mood, beyond the odd lexicalized use of an otherwise obsolete subjunctive form (e.g. moge). In this sense, constructions like (10) and (11) fill a clear functional niche in the grammar of Dutch, which may also explain why they have been mentioned occasionally in reference grammars and studies of subordination (e.g. De Rooij 1965: 117-121), together with their conditional insubordinate counterparts (see (61) below for an example).

We can distinguish two types of constructions within this category, on semantic and on formal grounds, viz. long-range and short-range wishes. The structures in (12)-(14) below illustrate long-range wishes. Semantically, they project the realization of the SoA beyond the immediate future. This can either mean they project a current SoA as continuing into the indefinite future, as in (12) or (13), where the speaker expresses their desire that the addressees' enjoyment and good health continue for an indefinite period. Or it can mean that they project the SoA as extending indefinitely from a future starting point, as in (14), where the speaker's desire does not apply to a specific instance of riding the motor bike, but the addressee's renewed ability to ride it (after an accident), marked by the particle weer 'again'. Incidentally, this also shows how an activity verb like crossen can be coerced into an uncontrolled interpretation: the long-range wish construction brings out the uncontrolled state of the ability to ride a bike, rather than the controlled activity of actually riding it. In either case, the long-range nature of the wish is formally reflected in the obligatory use of modal auxiliaries expressing potentiality, like mogen in (12) and (14) or kunnen in (13), often combined with particles expressing continuation, like nog in (12) and (13). 
(12) Dat je er nog lang van mag genieten.

CONJ you EXPL PART long PREP may.PRS enjoy

'I hope you will enjoy it for a long time.'

(13) Dat je nog vele jaren in goede gezondheid TL kan CONJ you PART many years in good health TL can.PRS verblijden met je kiekjes. please with your photos

'We hope you can please TL [name of a club] with your photos for many years to come, in good health.'

(14) Dat je maar snel weer mag crossen. CONJ you PART quickly PART may.PRS motor.ride 'I hope you can ride a bike again soon.'

Short-range wishes, by contrast, express the speaker's desire about one specific realization of a SoA, typically in the here-and-now or in the immediate future. Examples are provided in (15)-(17) below. Formally, they contain the particle maar, which is occasionally combined with a modal auxiliary, as with mogen in (17). Semantically, they project the realization of the desired SoA in the immediate future, as in (15) and (17), or in negative contexts, they project the aversion of an undesired state of affairs, as in (16). The specific nature of the wish may also explain why negative polarity is more common with short-range wishes than with long-range wishes.

(15) Dat ze maar gauw komen. CONJ they PART quickly come.PRS 
'I hope they will come soon.'

(16) Dat hij maar niet zeeziek wordt.

CONJ he PART NEG seasick become.PRS

'I hope he doesn't get seasick.'

(17) Dat het forum maar snel vol mag stromen.

CONJ ART forum PART quickly full may.PRS stream

'I hope the [on-line] forum gets filled up soon.'

The crucial formal difference between the two types of uncontrolled deontic insubordination is in the use of modal verbs like mogen and the particle maar: long-range wishes cannot leave out the modal verb, while short-range wishes cannot leave out maar. This can be illustrated by comparing the long-range wish in (14) and the short-range wish in (17), both of which have a combination of maar and mogen and are thus formally identical. As shown in (18) and (19) below, mogen can easily be dropped without losing the short-range interpretation (19b), while this is hard in the long-range wish (18b). Conversely, in the longrange wish maar can easily be dropped without losing the long-range interpretation (18c). This is harder in the short-range wish in (19c), where dropping the particle leads to a longrange interpretation that is strangely solemn for the event being described.

(18) Long-range wish (C, based on IC)

a. Dat je maar snel weer mag crossen.

b. ?Dat je maar snel weer crosst.

c. Dat je snel weer mag crossen.

(19) Short-range wish (C, based on IC)

a. Dat het topic maar snel vol mag stromen. 
b. Dat het topic maar snel volstroomt.

c. ?Dat het topic snel vol mag stromen.

The distinction between the two types also correlates with Aktionsart categories, in the sense that telic SoAs (accomplishments and achievements) are more typical with short-range wishes, while atelic ones (processes and activities, with the feature of control removed, as in (14)) are more typical with long-range wishes, as the wish often applies to continuation beyond a particular point. Unsurprisingly, states are neutral between the two, as shown in (20). Given that it is easy to construe a state like pijn hebben 'be in pain' both as a specific instance and a continuing experience, this allows both construal as a short-range wish and a long-range wish. Both of these possibilities are attested independently, as shown in (20a) and (20b).

(20) a. Dat je maar niet al te veel pijn hebt. CONJ you PART NEG all too much pain have.PRS 'I hope you won't be in too much pain.'

b. Dat je niet al te veel pijn mag hebben. CONJ you NEG all too much pain may.PRS have 'I hope you won't be in too much pain.'

Table 1 summarizes the formal and semantic features of uncontrolled deontic insubordination.

(Table 1 here)

\subsection{Controlled deontic insubordination}


Structures like (21)-(23) are different from uncontrolled insubordination in that the addressee is construed as having control over the realization of the SoA, and the speaker intervenes by telling the addressee (not) to realize it. Thus, the addressee in (21) is ordered not to think something, in (22) they are strongly advised not to fire someone, and in (23) they are invited to come and visit the speaker.

(21) Dat je maar niet denkt dat ik geen problemen heb hier. (IC) CONJ you PART NEG think.PRS CONJ I NEG problems have.PRS here 'Don't think that I don't have any problems here.'

(22) Dat hij maar eens probeert je te wippen, ik sla op zijn gezicht. (IC) CONJ he PART PART try.PRS you to fire, I beat.PRS on his face 'He'd better not try to fire you, or I'll punch him in the face.'

(23) Dat hij misschien eens langskomt. CONJ he perhaps PART visit.PRS

'He could perhaps come and visit.'

Like their uncontrolled counterparts, controlled deontic constructions can be subdivided into a number of distinct construction types, based on semantic and formal criteria. The most important semantic feature is the way speaker's and addressee's attitudes to the SoA are aligned or not, which correlates with the traditional distinction between strong and weak deontic categories. With strong categories like obligation and prohibition, the addressee's and the speaker's desires are typically opposite: the addressee does not want what the speaker wants (in the case of obligation) or the other way around (in the case of prohibition). With weak categories like permission and advice, the addressee's and the speaker's attitudes are 
typically aligned: the addressee either wants the same as the speaker or is neutral (see further in Verstraete 2005b). The same contrast applies to controlled deontic types, which means that unlike with uncontrolled types they have a clear parallel in the more grammaticalized system of mood and modality in Dutch. Even here, however, the insubordinate types are more restricted and semantically more specific than their standard modal counterparts.

\subsubsection{Strong deontic modality}

In structures with strong deontic modality, speakers express their desire about the SoA to a strong degree, and their attitude is typically opposed to the addressee's presumed attittude: they order the addressee to do something the addressee does not want (orders), or they forbid the addressee to do something the addressee wants or is about to do (prohibitions). In standard deontic exponents like imperatives and modal verbs, both of these options are available, as shown in (24) and (25).

(24) Geef me de afstandsbediening!

give.IMP me ART remote.control

'Give me the remote control!'

(25) Ze mogen hier de grens niet oversteken.

they may.PRS here ART border NEG cross

'They are not allowed to cross the border here.'

In insubordinate constructions, by contrast, the range of options is more limited. First, strong deontic types are limited to negative contexts, i.e. they can express prohibitions but not orders. Thus, for instance, an affirmative insubordinate construction expressing a direct order 
to a second or third person like (26) is generally excluded in Dutch, ${ }^{6}$ even though it is easily available in related languages like German (see examples in Panther \& Thornburg 2011, and further in section 5 of this paper).

(26) *Dat je/hij maar recht naar school gaat!

CONJ you/he PART straight to school go.PRS

'You/he must go straight to school.'

Second, even the negative constructions are semantically more specific than their counterparts with moods or modals. While strong deontic insubordination is in principle available in simple clauses, as in (27), by far the most typical instances are insubordinate clauses that have a further complement clause, like (28) and (29). Semantically, in all three cases speakers express their desire that the addressee refrain from an action they are planning to do or are about to do: not to rely on old songs for too long in (27), not to forget the speaker's love in (28), and not to take a specific role in a computer game in (29).

(27) Dat ze maar niet te lang blijft teren op die paar goeie liedjes. (IC) CONJ she PART NEG too long keep.PRS rely on DEM couple good songs 'She shouldn't keep relying on those couple of good songs [she made].'

(28) Dat je maar niet vergeet dat ik nog altijd van je hou. (IC) CONJ you PART NEG forget.PRS CONJ I PART always PREP you love.PRS 'Don't forget I still love you.'

(29) Dat je het niet waagt als disc te gaan raiden. CONJ you EXPL NEG dare.PRS as disc to go raid

\footnotetext{
${ }^{6}$ Some speakers note that orders are marginally possible if they are preceded by the coordinator en 'and', for instance coordinated with imperatives.
} 
'Don't dare to go and raid as a disc [role in a computer game].'

Pragmatically, however, the presence of a second complement clause in (28) and (29) can make a difference in the final interpretation. With a propositional complement to a verb of cognition, like vergeten 'forget' in (28) or denken 'think' in (21) above, the insubordinate structure comes to function as a strong assertion, viz. that the speaker still loves the addressee in (28) and that the speaker has lots of problems in (21). With a complement to a verb like wagen 'dare' in (29), the final interpretation remains prohibitive, but the prohibition pertains to the verb of the second complement ('don't raid') rather than the first. In both cases, the first verb is to some degree transparent, shifting the focus to the verb in the second complement clause (compare Van linden 2012 for a parallel instance in the domain of subordinate complementation).

Formally, these prohibitions often use the particle maar, but unlike in short-range wishes it can easily be left out, as shown in (29). This is also how prohibitions can be distinguished from short-range wishes. In principle, a structure like (27) is ambiguous between a prohibition and a short-range wish. In the prohibitive interpretation, relying on old songs is construed as something that is under the singer's control, something she is planning to do but which the speaker doesn't think is a good idea. In the optative interpretation, by contrast, relying on old songs is construed as something that is not under the singer's control (e.g. a pattern she could slip into when she becomes successful), which the speaker hopes will not happen. Using the formal difference with maar, it is easy to distinguish between the two. Thus, a structure like (30), with maar left out, has a prohibitive interpretation and is harder to interpret as a wish. 
(30) Dat ze niet te lang blijft teren op die paar goeie liedjes! (C, based on IC) CONJ she NEG too long keep.PRS rely on DEM couple good songs 'She shouldn't keep relying on those couple of good songs [she made].'

\subsubsection{Weaker deontic types}

With weaker deontic modality, speakers express their desire for the realization of the SoA less strongly, and typically the addressee's presumed attitude is not opposed to their own: they give them permission (not) to do something, i.e. with the same attitude on the part of the addressee, or they advise them (not) to do something, often with neutral attitudes on the part of the addressee. Both of the more typical exponents of deontic modality are available for this type, i.e. imperatives, as in (31), and modal verbs, as in (32).

(31) Neem je fiets maar mee.

take.IMP your bike PART along

'Just take along your bike.'

(32) Ze hoeven hun huiswerk niet te maken.

they MOD.PRS their homework NEG to make

'They don't have to make their homework.'

As with stronger types of deontic modality, insubordinate constructions are more restricted than the more typical exponents. Specifically, we only find affirmative types for weak deontic insubordination, like (33)-(37) below.

(33) Dat ze ze maar meebrengt zondag.

(CGN) 
CONJ she them PART bring.along.PRS Sunday

'She can bring them on Sunday.'

(34) Dat ie maar gerust zo verder doet.

CONJ he PART PART DEM PART do.PRS

'He can just continue what he is doing right now.'

(35) Dat hij dat maar eens bewijst met cijfers.

CONJ he DEM PART PART prove.PRS with figures

'He should back it up with figures.'

(36) Dat hij misschien eens in zijn achterzak kijkt.

CONJ he perhaps PART in his back.pocket look.PRS

'He could try and check his back pocket.'

(37) Dat hij eens probeert in een Dakar of zo.

CONJ he PART try.PRS in ART Dakar or DEM

'He could try taking part in the Dakar race or something like that.'

The link with affirmative constructions is confirmed by the fact that negatives tend to receive a strong modal interpretation, i.e. as prohibitive rather than permission or advice. This is the case even when the predicate used suggests the addressee would not normally want the SoA. In (38), for instance, doing homework is not normally something to be desired by the addressee, but the negative construction still induces a prohibitive reading rather than a permissive one: the structure in (38) suggests that the addressees want to do their homework but are prevented by the speaker. This is illustrated by the way it can easily be followed by a threat (e.g. 'or else I'll tear it up').

(38) Dat ze hun huiswerk maar niet maken.

(C) 
CONJ they their homework PART NEG make.PRS

'They shouldn't make their homework.'

Apart from the restriction on polarity, the weaker deontic type is formally and semantically less restricted than the stronger deontic type, and similar to its counterparts with imperatives and modal verbs. The range of particles, for instance, is the same as used with imperatives and modal verbs. Thus, we find particles like maar, misschien, gerust and eens, which can occur on their own or in combination, as illustrated in (33)-(37). Unlike with the stronger deontic type, it is not easy to leave out the particles. Semantically, these particles serve to further specify the schematic meaning of weak deontic modality, usually in the same way as they do with imperatives or modal verbs. Using gerust or gerust eens, for instance, leads to a specification of permission: a structure like (39) is a natural response to a request for permission. The semantics of gerust provides the link with permission: gerust is identical to an adjective that means 'with one's mind at ease'. With this form, the speaker reassures the addressee that they should not worry about the speaker's willingness to have them visit.

(39) A: Jan zou graag langskomen.

Jan would PART come.along

'Jan would like to come and visit.'

B: Dat hij gerust/*misschien langskomt.

CONJ he PART come.along.PRS

'He can just come and visit.'

Particles like misschien, eens or misschien eens, by contrast, can be used to trigger interpretations of advice, in cases where it is not obvious that the addressee has thought of the 
action in question. For instance, structures with misschien and eens like (36) or (37) above can easily be used in contexts where the addressee is at a loss what to do, as shown in (40), but they cannot be used in response to requests for permission, as shown in (39). Conversely, structures with gerust that are normal in permission contexts like (39) could not be used in advice contexts like (40). The link with advice is in the semantics of the particles, which open up a possibility, either in terms of modality (with epistemic misschien 'perhaps'), or in terms of quantification (with the open event quantifier eens 'once').

(40) A: Jan heeft zijn portefeuille verloren.

Jan have.PRS his wallet lose.PTCP 'Jan has lost his wallet.'

B: Dat hij misschien eens/*gerust in zijn achterzak kijkt. CONJ he perhaps PART in his back.pocket look.PRS 'He could try and check his back pocket.'

In contrast to the other particles, maar (also found in wishes and prohibitions) is far more versatile, triggering several different types of interpretation. This versatility can be explained in terms of its meaning, which is more schematic than the particles considered above. As shown in Foolen (1993), in imperative contexts the use of maar entails the existence of some barrier towards the realization of the SoA. This may be due to the addressee who has doubts whether the speaker really wants it, as in (41), or to the speaker who may not really think it's a good thing, as in (42). An example like (41) could be used in response to a visitor's checking if their visit is timely, in which case maar signals "recognition of the addressee's hesitation" (Foolen 1993: 133) and triggers an interpretation of permission. An example like (42) could be used in response to repeated requests to visit, in which case maar 
signals the existence of a problem on the part of the speaker, and triggers an interpretation of grudging acquiescence, i.e. with permission counterbalanced by a negative attitude towards the visit.

(41) Ja hoor, kom maar binnen.

(Foolen 1993: 177)

yes PART come.IMP PART in

'Sure, come on in.'

(42) Oké, kom dan maar.

(Foolen 1993: 177)

allright come.IMP PART PART

'Allright then, come in.'

The same mechanism works for its insubordinate equivalents: the invocation of different types of barriers explains why maar in weaker deontic insubordination can signal both permission, as in (33) above, and indifferent or skeptical advice, as in (43) and (44) below. The clause in (33) is a response to a question (whether a set of statues could be of any use to the speaker): in this case, the speaker uses maar to counter the addressee's hesitation, i.e. that they should not feel any reservation to bring the statues. The clause in (43), by contrast, is used in a context where the speaker has voiced her concern about investments: in this case, the speaker uses maar to signal that permission really goes against her own hesitations, yielding an interpretation of indifference. The clause in (44) is used in a context where the speaker is unsure if the addressee will actually pay attention to his warning: in this case, maar is used to signal that the speaker's advice counters his expectations about what the addresee will really do.

(43) Als mijn man zijn geld wil investeren, dat hij dat maar doet. (IC) 
CONJ my husband his money want.PRS invest, CONJ he DEM PART do.PRS

'If my husband wants to invest his money, he should just go ahead and do it.'

(44) Dat hij maar goed oplet.

CONJ he PART well be.careful.PRS

'He should be very careful.'

In combination with eens, maar can even mark a challenge to the addressee and trigger a pragmatic reversal of a structure's surface polarity. This is illustrated in (45) and (46) below. In both instances, maar is of the type found in (43) and (44), because it signals a barrier on the part of the speaker. In (45) it signals a barrier in terms of the speaker's attitudes (the speaker does not want the addressee to fire her), and in (46) the barrier is in terms of their expectations (the speaker does not the addressee to come up with figures to back up their claim).

(45) Dat hij maar eens probeert je te wippen, ik sla op zijn gezicht. (IC) CONJ he PART PART try.PRS you to fire, I beat.PRS on his face 'He'd better not try and fire you, I'll punch him in the face.'

(46) Dat hij dat maar eens bewijst met cijfers. CONJ he DEM PART PART prove.PRS with figures 'He should come up with figures to prove it (but I doubt if he can).'

The combination with eens leads to an explicit challenge, because as an open event quantifier it marks a suggestion to the addressee. This counteracts the negative barrier marked by maar, and thus leads to ironic reversal. In a structure like (45), moreover, the event-initiating verb proberen further strengthens polarity reversal: (45) is interpreted as 'don't try to fire her', which together with the next clause expresses a threat. Even though these constructions have 
the basic form and meaning of weak deontic modality, the polarity reversal triggered by the combination of particles in (45) and (46) pragmatically pushes their interpretation towards the stronger deontic category.

Table 2 summarizes the different types of controlled deontic insubordination discussed in this section.

(Table 2 here)

\section{Evaluative insubordination}

While deontic insubordination deals with potential SoAs, evaluative insubordination marks the speaker's evaluation of the occurrence of an actual SoA. For instance, in structures like (47)-(49), the issue is not the desirability of some potential SoA, but an evaluation of its realization, current, past or even future (in the case of pre-arranged SoAs). The availability of non-present forms is the most obvious formal difference from the deontic category, but there are more differences, as will be shown further on in this section. As with the uncontrolled deontic category, there are no clearly grammaticalized equivalents for this type of meaning in Dutch. There is only a range of semantically specific lexical items, like predicates of surprise, disgust or appreciation that can head the subordinate counterparts of (47) and (48). Again, therefore, this type of insubordination occupies a clear functional niche in the language, because it offers a more general construction type for marking evaluation. This niche may also explain why these types have occasionally been listed as a problematic type of subordination in reference grammars of Dutch and other works (e.g. van der Horst 1984: 162). More generally, König \& Siemund (2012) have argued that evaluative types of functions (often called 'exclamative' in the literature) form a natural niche for insubordinate 
constructions, given that such functions tend not to figure in more grammaticalized paradigms of mood, modality or basic clause types.

(47) Dat u dat durft te zeggen. $(\mathrm{CGN})$ CONJ you DEM dare.PRS to say 'I can't believe you dare to say that.'

(48) Dat het zo ver is gekomen. CONJ it so far be.PRS come.PTCP 'That it should have come to this.'

(49) Dat u weer zoiets moet overkomen.

CONJ you again such.thing must.PRS happen

'Why does this have to happen to you again?'

Within the evaluative category, we can distinguish between two construction types, viz. unexpected and expected evaluation, each with its own semantics and formal marking. The first type is illustrated in (47)-(48) above, and in (50)-(52) below. In this type, the SoA is evaluated as unexpected, and typically, but not necessarily, negative. In (47)-(48) and (50)(52), the speaker expresses their surprise that something has happened or is happening: that the addressee has made a provocative statement in (47), that things have developed so badly in (48), that people are very cold-hearted in (50), that the speaker can still witness something in (51), and that the addressee is so slow to find out in (52). The evaluation is typically negative, as in (48), (50) and (52), but there are also neutral or positive instances, like (47) and (51).

(50) Dat iemand zo hard kan zijn. 
CONJ someone so hard MOD.PRS be

'I can't believe anyone can be so cold-hearted.'

(51) Dat ik dat nog mag meemaken.

CONJ I DEM still may.PRS live

'I never thought I would live to see this.'

(52) Dat je dat nu pas weet.

CONJ YOu DEM nOw PART knOw.PRS

'I can't understand you've only just found out.'

Formally, this type is characterized by the use of scalar marking in the broad sense, i.e. scalar particles like zo 'so' in (48) and (50), scalar temporal expressions like nu pas 'only now' in (52), event-initiating verbs like durven 'dare' in (47), or instances of contrastive focus like the focus on demonstrative dat in $(51)^{7}$ What all of these markers have in common is that they locate the SoA at the extreme of a scale: explicitly, with scalar elements, or implicitly, with focus creating a scalar relation between the focused element and its presupposed alternatives, or event-initiating expressions creating a scale from initiating to acting. The location at the extreme of a scale is what becomes the subject of the evaluation of the state of affairs as unexpected. We often also find these markers in combination, as in (53) which has a scalar expression zelfs 'even', an event-iniating expression denken aan 'consider', and a focus on denken 'think'.

(53) Dat je er zelfs maar aan denkt om zoiets te zeggen. (IC) CONJ you PART even PART PREP think.PRS for such.thing to say

\footnotetext{
${ }^{7}$ This would be marked prosodically in the spoken equivalent. As noted by a reviewer, aspects of prosody may play a more systematic role as formal features to distinguish types of insubordination, especially as they relate to aspects of information structure.
} 
'I can't believe you even consider saying something like that.'

The second type of evaluative insubordination is illustrated in (49) above, and in (54)(55) below. Unlike with the first type, the SoA in these constructions is evaluated as expected, or at least following an expected pattern, and always as negative. Basically, the construction expresses the speaker's annoyance at a development that is not unexpected, like the fact that it is always Tom who causes trouble in (54), or the fact that problems with children invariably occur at night in (55). Formally, this type is characterized by markers of repetition and continuity, like weer 'again' in (54) and altijd 'always' in (55), or inevitability, like the modal verb of necessity moeten in (49) and (54)-(55). In contrast to scalar markers, which boost the unexpectedness of the state of affairs, this set of markers serves to downtone it, leading to an evaluation of an event as unavoidable and negative.

(54) Tom, dat je weer zoiets moet flikken.

Tom CONJ you again such.thing must.PRS do

'Tom, why did you have to do that again?'

(55)

Dat zoiets ook altijd 's nachts moet gebeuren!

CONJ such.thing PART always at.night MOD.PRS happen

'Why does something like that always have to happen at night?'

Taken together, the formal markers of the two types of evaluative insubordination can also be used to distinguish the evaluative type from its deontic counterparts. As shown in (56), for instance, replacing maar in the deontic structure in (56a) with a scalar expression like zelfs hier shifts the interpretation from weak deontic modality to an evaluation of the event as 
unexpected in (56b), and replacing it with weer and the modal of necessity moeten shifts it to an evaluation as expected and negative in (56c).

(56) a. Dat hij maar slaapt.

CONJ he PART sleep.PRS

'I'd suggest he try and sleep.'

b. Dat hij zelfs hier slaapt.

CONJ he even here sleep.PRS

'I can't believe he can sleep even here.'

c. Dat hij nu weer moet slapen.

CONJ he now PART MOD.PRS sleep

'Why does he have to sleep again now?'

Table 3 summarizes the different types of evaluative insubordination.

(Table 3 here)

\section{Discursive insubordination}

The final category of insubordination is discursive insubordination. In this type of structure, the speaker does not express any attitude, deontic or evaluative, towards the SoA, but uses an insubordinate construction to expand on and clarify an utterance from the preceding discourse. Examples are presented in (57)-(59) below, with some context and the relevant material underlined in the translation. 
(57) A: En in één keer gaat dat vliegtuig een vaart maken om de lucht in te komen. Nou ik denk wat gebeurt hier. Net een hele snelle lift he.

$(\mathrm{CGN})$

B: ggg. Ja.

A: Dat je zo omhoog gaat. CONJ you DEM up go.PRS

'A: And all at once the plane speeds up to get into the air. I thought what's going on here. Just like a very fast elevator isn't it. B: Yes. A: When you go up like that.'

(58) A: Hebben jullie wel een pad hierachter?

B: Ja.

A: Dat je zo met de fiets achter langs kan.

$(\mathrm{CGN})$ CONJ you DEM with ART bike behind PART can.PRS

'A: Do you have a path behind (the garden)? B: Yes. A: Where you can reach the garden from the back with your bike.'

(59) A: Prima als je je vrienden uitnodigt maar niet weer half Budel $\quad$ (CGN) B: Mmm.

A: Omdat die feesten die ze dan uh ja ooit zo in die garage heeft daar is ja.

B: Ja.

A: Die lopen net zo uit de hand als die feesten die we bij Judith en Jacques in de tuin altijd geven.

Dat je echt zo tachtig of honderd man uitnodigt. CONJ you really DEM eighty or hundred man invite.PRS

'A: It's OK if you invite friends, but not half the town. B: Mmm. A: Because those parties she has in the garage there's ... B: Yes. A: They get out of hand as easily as those parties we always have at Judith and Jacques' in the garden. When you invite eighty or a hundred people.' 
In each of these structures, the insubordinate structure explains an aspect of the preceding discourse, without being formally attached to any specific element from that discourse. In (57), it explains why the feeling of a plane taking off is like a fast elevator, in (58) it explains the relevance of asking about a path behind one's garden ${ }^{8}$, and in (59) it explains how parties may get out of hand. Formally, these structures have none of the features found in deontic and evaluative insubordination, but they often contain the manner demonstrative zo 'like that' (homophonous with the scalar element zo discussed in section 3), which marks their function of expanding on and explaining what went before.

This use has not been described in Dutch, but Evans (2007) provides an analysis of a parallel use in German, citing Schlobinski (n.d.). Specifically, he shows that the explanatory and expanding functions can be used interactively in therapeutic discourse, with complement insubordination providing the therapist's restatement of the client's preceding turn. The functions of the Dutch counterpart appear to be similar, but a detailed study of its interactive functions are beyond the scope of this paper. The identification of a separate discursive type, distinct from the evaluative and deontic types, is sufficient for the purposes of our constructional typology.

\section{A typology of construction types}

From a semantic perspective, the range of types found in Dutch complement insubordination confirms what we know about the typology of insubordinate constructions. Evans (2007,

\footnotetext{
${ }^{8}$ As noted by Ekkehard König (p.c.), complement insubordination of the discursive type can shade into interpretations of consequence or purpose, as may be the case here (the speaker expands on their own previous turn by explaining the consequence of having a path behind one's garden). In Dutch and German such constructions can also use the general subordinator dat, in addition to semantically more specialized subordinators like zodat and opdat.
} 
2009) suggests that insubordination is never semantically neutral, but typically has attitudinal and interactional types of functions (see also Boogaart 2011, Foolen 2012). All of the constructions investigated here fall within this broad domain, marking attitudes of the speaker (the evaluative and uncontrolled deontic categories), negotiation between speaker and addressee (the controlled deontic category), and the organization of information in interaction (the discursive category). What is perhaps more interesting than the semantic range, however, is the fact that this broad range is expressed by what formally looks like variants of a single construction type, using the same combination of complementizer dat and verb-final word order. This makes the situation in Dutch an interesting case study for the relation between the different insubordinate types. In standard constructional analysis, formal and semantic similarities between construction types suggest that they may be analysed as instances of a more schematic construction, and that their specific meanings could be derived from a more schematic meaning (for instance in terms of the interaction with particles that distinguish the different insubordinate types). In this section, we will show that it is difficult to come up with a schematic analysis that covers all types of complement insubordination. We will argue that this lack of unity is due to its unusual origins in the ellipsis of main clause material, and the subsequent conventionalization of information associated with the entire main-subordinate construction.

Table 4 below summarizes the types discussed in the previous sections, with the basic semantic categories on the left, and the formal markers associated with each semantic category on the right.

(Table 4 here) 
Each of these form-meaning pairings is, of course, sufficient evidence to posit a distinct construction in the classical sense (e.g. Goldberg 1995). Still, the analysis in the previous sections implicitly suggests a clustering in terms of more schematic types, viz. deontic, evaluative and discursive insubordination. At first sight, this appears to be supported by the availability of distinct sets of formal markers to distinguish the types. We could posit a schematic evaluative type that marks the speaker's evaluation of a state of affairs, for instance, with the unexpected and the expected types derived by the use of scalar and non-scalar expressions, respectively. Similarly, we could posit an uncontrolled deontic type, with the short-range and long-range types derived by the use of modal verbs and particles, respectively, and so on for higher-level clusterings, until we come to an overarching construction schema for the whole domain of complement insubordination. Although the form of the constructions suggests that such an overall schema is possible, there are a number of problems with this analysis.

The first problem is the lack of motivation for specific (sets of) formal features that identify the types. Arbitrariness is, of course, unproblematic from the perspective of the seven individual constructions, but if we want to analyse them as specific instances of more schematic types, semantic motivations of the formal differences are crucial to explain how and why the different levels are related. Thus, for instance, there is an obvious functional link between the formal feature of scalarity and the semantic feature of unexpectedness, which can be used to motivate a derivation of the two evaluative types from a more schematic evaluative construction. By contrast, it is hard to think of any good functional link between the formal features of negative polarity and double complementation and the semantic feature of strong deontic modality, even though these characteristics are what distinguish between the strong and the weak types of controlled deontic modality. The arbitrariness of such features is even clearer from a comparative perspective. While Dutch excludes affirmative strong deontic 
constructions like (60a), they are unproblematic in German, which allows both negative and affirmative strong deontic modality in at least some insubordinate constructions, with and without double complementation, as shown in (60b) and (60c) (see more examples in Panther \& Thornburg 2011: 101-104). This shows clearly that there is no obvious functional basis to some of the features that define specific types of insubordination, which of course makes it difficult to use them to demonstrate higher-level clustering into schematic construction types.

(60) a. *Dat je maar je huiswerk maakt!

CONJ you PART your homework make.PRS

'You should do your homework.'

b. Dass du dich ja anständig benimmst CONJ you REFL PART appropriately behave.PRS

'Behave appropriately by all means.' (Panther \& Thornburg 2011: 89)

c. Dass du ja nicht denkst, du kannst heute wieder faulenzen (IC) CONJ you PART NEG think.PRS you can.PRS today PART be.lazy 'Don't think you can be lazy again today.'

A second problem is the semantic motivation of higher-level clustering itself. While some instances of clustering make sense semantically, even if there is no good formal evidence, other groupings seem much more arbitrary. For instance, while long-range and short-range wishes can be grouped together as instances of complement insubordination, some varieties of Dutch group short-range wishes with an entirely different construction type altogether. Netherlandic varieties of Dutch (see De Rooij 1965 for details) use conditional insubordination for short-range wishes, as shown in (61) below, and use complement insubordination only for long-range wishes. Similarly, German separates long-range wishes 
from their short-range counterparts in terms of the use of complex form auf dass instead of the standard complementizer dass.

(61) Als hij maar niet valt.

CONJ he PART NEG fall.PRS

'I hope he doesn't fall.'

Semantic motivations are even more problematic once we try to analyse deontic, evaluative and discursive types as instances of one very general type. Deontic insubordination deals with the desirability of potential SoAs, evaluative insubordination deals with the expectedness of actual SoAs, and discursive insubordination does not have any attitudinal value at all but simply marks a discursive relation. It is hard to see what could motivate analysing this as instances of a more schematic construction, and what semantic value we could attach to it. There are, of course, semantic links between evaluation and deontic modality in the literature (e.g. Van der Auwera \& Plungian 1998), but these usually involve evaluation in a different sense, with expressions of goodness and suitability (rather than expectedness) serving as historical sources for deontic expressions. In addition, there have been proposals for a more general schematic meaning for (subordinate) complement constructions, like Verhagen (2005), who argues that they have a basically intersubjective function, with the complement-taking clause "instruct[ing] the addressee to construe it in a particular way and thus to engage in cognitive coordination with another subject of conceptualization" (2005: 150). ${ }^{9}$ This type of analysis of complement constructions may well explain why insubordination in this domain tends to have attitudinal and interactional functions, but it is too schematic to serve as the basis for a constructional generalization. A

\footnotetext{
${ }^{9}$ We are grateful to a reviewer for pointing out the relevance of this work.
} 
generalization should be able to predict not only the types that occur (e.g. deontic negotiation and evaluation), but also those that do not occur (e.g. epistemic negotiation, an important domain in standard complement constructions, which seems to be absent in complement insubordination). Moreover, even if we could assign a schematic value to complement insubordination in general, it is not clear how the specific sets of formal markers listed in Table 4 could motivate its relation to the mid-level schematic types of deontic, evaluative and discursive insubordination.

A final problem with attempts to generalize over types of complement insubordination concerns variation in the relation to their standard subordinate counterparts. Some types are formally identical to their subordinate counterparts and could easily have a main clause reconstructed, while others have formal features that prevent the reconstruction of a main clause, and still others do not have any obviously reconstructable main clause at all. Uncontrolled deontic and evaluative constructions illustrate the first category: they are identical to standard subordinate types, and can have a main clause added without any problem, as illustrated in (62) below. ${ }^{10}$ In this structure, the complement clause could just as easily function as a complement to the main clause and as an insubordinate construction: there is nothing to distinguish the internal structure of subordinate and insubordinate counterparts.

(62) a. [Ik wens] Dat jullie nog lang samen gelukkig en gezond I wish CONJ you PART long together happy and healthy bij elkaar mogen blijven! with each.other may.PRS stay 'I wish you can stay together, happy and healthy, for a long time.' b. [Ik hoop] Dat hij maar niet crasht.

\footnotetext{
${ }^{10}$ Of course, a range of predicates is possible for each example. What matters is not which specific type of main clause is added, but that it is structurally possible to add one.
} 
I hope CONJ he PART NEG crash.PRS

'I just hope he doesn't crash.'

c. [Het is ongelooflijk] Dat $u$ dat durft te zeggen.

it is incredible CONJ you DEM dare.PRS to say

'I can't believe you dare to say that.' (all C, based on IC)

Controlled deontic constructions illustrate a different type: in many instances it is structurally impossible to reconstruct a main clause. The crucial element here is the particle maar. Controlled deontic constructions with maar do not allow reconstruction of any main clause, as shown in (63a) and (64a): it has to be removed before they can function as a subordinate clause, as shown in (63b) and (64b). The reason is that maar is a typical main clause marker in deontic contexts: as explained in section 2.2.2, it has a parallel distribution and function in imperative clauses, which is probably also what its use in deontic insubordination is modelled on. The problem here is not semantic, therefore, but purely structural, because of the presence of a marker that blocks the reconstruction of an accompanying main clause for the insubordinate clause.

(63) a. [*Ik wil/beveel] Dat hij maar niet denkt ...

I want/order CONJ he PART NEG think.PRS

b. Ik wil/beveel dat hij niet denkt...

I want/order CONJ he NEG think.PRS

'I don't want him to think that ...'

(64) a. [*Ik raad aan/laat toe] Dat ze ze maar meebrengt zondag I advise/allow CONJ she them PART bring.along.PRS Sunday b. Ik raad aan/laat toe dat ze ze meebrengt zondag. 
I advise/allow CONJ she them bring.along.PRS Sunday

'I would advise/permit her to bring them along on Sunday.'（all C, based on IC)

The discursive category, finally, is different from the previous two in that it is hard to reconstruct any main clause at all, not for structural reasons, but for semantic reasons. A structure like (65) below does not have any obvious main clause that could be reconstructed. The closest approximation would be a reformulation predicate like ik bedoel dat 'what I mean to say is that', but even that may be reading too much into the data. Instead, it looks like the insubordinate clause relates to the speaker's entire preceding turn, and could therefore be regarded as instantiating a form of discourse dependency rather than the structural dependency of subordination, a point that has also been made by Mithun (2008), who focuses specifically on the way 'insubordinate' types of constructions function in broader discourse contexts.

(65)A: En in één keer gaat dat vliegtuig een vaart maken om de lucht in te komen. Nou ik denk wat gebeurt hier. Net een hele snelle lift he.

$(\mathrm{CGN})$

B: ggg. Ja.

A: Dat je zo omhoog gaat. CONJ you DEM up go.PRS

'A: And all at once the plane speeds up to get into the air. I thought what's going on here. Just like a very fast elevator isn't it. B: Yes. A: When you go up like that.'

We believe that this final problem - different types of relations to subordinate structures - goes to the heart of the question why it is hard to come up with a constructional generalization for complement insubordination, in spite of the apparent formal unity of the 
seven types discussed in this paper. The commonalities we can observe are due to a common origin in a complement clause, but the real point of origin for each construction type is not the complement clause as such, but a larger construction consisting of a main clause and a complement clause. Even if the main clause is elided in the development of insubordination, the constructions still bear its traces, semantically and formally. Thus, for instance, the formal features that distinguish evaluative types from uncontrolled deontic types are the same ones that distinguish complements to predicates of surprise and disbelief from complements to predicates of wishing and hoping. Scalar expressions are found both in complements of surprise and disbelief predicates and in evaluative insubordination, while modal verbs of potentiality are found both in complements of hoping and wishing predicates and in uncontrolled deontic insubordination. Moreover, the controlled deontic type shows that once an insubordinate type has taken over a semantic feature from the main-subordinate construction in which it originates, it can also take over formal features from semantically analogous main clauses, like the use of the particle maar by analogy with imperative constructions. From this perspective, it is not surprising that it is difficult to come up with a constructional generalization over the different types of complement insubordination: each originates in a different type of main-subordinate construction, and has a different degree of conventionalization. Evaluative constructions are structurally fairly close to their subordinate origins, while controlled deontic types have moved away much further, and taken over formal features from their standard modal counterparts.

\section{Conclusion}

In this study, we developed a typology of complement insubordination in Dutch, using formal and semantic criteria to distinguish seven construction types in three broad semantic 
categories. The analysis testifies to the wealth of insubordination phenomena in this language, as in other Germanic languages, which has barely been touched upon in the literature. From a semantic perspective, the range of meanings expressed by complement insubordination nicely confirms the semantic range predicted more generally by Evans (2007). From a constructional perspective, moreover, the Dutch data can help us better understand the nature and origins of insubordination, which as mentioned above appear to go against classic mechanisms of change in the domain of complex sentences. The apparent formal unity of the phenomena in Dutch provides us with an interesting case study to test the constructional status of insubordination, and ultimately also a glimpse at its origins. In spite of their overall formal similarity, the different types of complement insubordination in Dutch appear to form separate constructions that cannot easily be unified as instances of a more schematic type: it is difficult to generalize semantically, it is hard to motivate the formal characteristics that distinguish the types, and each type has quite different relations to its subordinate counterparts. All of this suggests that the different types of complement insubordination have their origins in different types of main-subordinate constructions, that they followed separate paths in their development, and that they show different degrees of conventionalization as main clauses, as predicted by Evans' (2007) general model for the development of insubordinate constructions.

Our analysis has merely scratched the surface of insubordination phenomena in Dutch, and has glossed over a large number of questions that remain open. From a descriptive perspective, for instance, the semantic analysis of the constructions needs much more work, especially in comparison with the standard modal and evaluative resources in the language. To give just one example, we have not been able to analyse in any detail what the relation is between the interlocutor and the target of the deontic judgement in controlled deontic constructions. Our analysis has glossed over this distinction by using the general term 'addressee' (see footnote 2), but in many instances, the two are not the same. This mismatch 
can give rise to different types of pragmatic strategies that are not available for standard modal constructions, and thus creates a special functional niche for controlled deontic insubordination.

From a more general perspective, the phenomena discussed here also suggest a number of interesting comparative and diachronic questions. For instance, we have not been able to devote much attention to the counterparts of complement insubordination in related varieties and languages. The data we looked at in section 5 (in varieties of Netherlandic Dutch and German) suggest that a more thorough comparative study could strengthen our general point about the underlying diversity of complement insubordination, with comparable types of insubordination ending up with differing degrees of conventionalization in related languages. In addition, we have only been able to study the origins and development of insubordination in an indirect way, by looking at the constructional diversity of the synchronic material. It would be interesting to see if this analysis is borne out in a diachronic study, if at least it is possible to find the type of semi-spoken material that is likely to contain instances of insubordination and its precursors.

\section{$\underline{7 . \text { References }}$}

Boogaart, Ronny. 2010. De verzuchtingsinfinitief. Vaktaal 23. 9-10.

Boogaart, Ronny. 2011. Over insubordinatie gesproken! Presentation at the University of Leuven.

De Rooij, Jaap. 1965. Als - of - dat. Enkele conjuncties in ABN, dialect en Fries. Assen: Van Gorcum.

D’Hertefelt, Sarah. 2010. Geïnsubordineerde constructies in het Nederlands: een studie vanuit typologisch perspectief. Leuven: University of Leuven MA thesis. 
Evans, Nicholas. 1993. Code, inference, placedness and ellipsis. In William Foley (ed.), The role of theory in linguistic description, 243-280. Berlin: Mouton de Gruyter.

Evans, Nicholas. 2007. Insubordination and its uses. In Irina Nikolaeve (ed.), Finiteness. Theoretical and empirical foundations, 366-431. Oxford: Oxford University Press.

Evans, Nicholas. 2009. Insubordination and the grammaticalization of interactive presuppositions. Paper presented at Methodologies in determining morphosyntactic change. Osaka. http://www.r.minpaku.ac.jp/ritsuko/english/symposium/pdf/symposium_0903/Evans_ha ndout.pdf. (7 January, 2010.)

Foolen, Ad. 1993. De betekenis van partikels. Een dokumentatie van de stand van het onderzoek, met bijzondere aandacht voor 'maar'. Nijmegen: University of Nijmegen dissertation.

Foolen, Ad. 2012. The relevance of emotion for language and linguistics. In Ad Foolen, Ulrike Lüdtke, Jordan Zlatev \& Tim Racine (eds.), Moving ourselves, moving others: Motion and emotion in intersubjectivity, consciousness and language, 347-368. Amsterdam: John Benjamins.

Goldberg, Adele. 1995. Constructions. A construction grammar approach to argument structure. Chicago: University of Chicago Press.

Haeseryn, Walter, Kirsten Romijn, Guido Geert, Jaap de Rooij \& Maarten van den Toorn. 1997. Algemene Nederlandse spraakkunst, 2nd edn. Groningen: Martinus Nijhoff. Halliday, Michael. 1970. Functional diversity in language as seen from a consideration of modality and mood in English. Foundations of Language 6. 322-361.

Hopper, Paul \& Elizabeth Traugott. 2003. Grammaticalization. Cambridge: Cambridge University Press.

Kiefer, Ferenc. 1997. Modality and pragmatics. Folia Linguistica 31. 241-253. 
König, Ekkehard \& Peter Siemund. 2012. Satztyp und Typologie. In Jörg Meibauer, Markus Steinbach \& Hans Altmann (eds.), Satztypen des Deutschen. Berlin: Mouton de Gruyter. Mithun, Marianne. 2008. The extension of dependency beyond the sentence. Language 83. 69-119.

Nuyts, Jan. 2005. The modal confusion: On terminology and the concepts behind it. In Alex Klinge \& Henrik Høeg Müller (eds.), Modality: Studies in form and function, 5-38. London: Equinox.

Nuyts, Jan, Pieter Byloo \& Janneke Diepeveen. 2010. On deontic modality, directivity, and mood: The case study of Dutch mogen and moeten. Journal of Pragmatics 42. 16-34. Palmer, Frank. 2001. Mood and modality, $2^{\text {nd }}$ edn. Cambridge: Cambridge University Press. Panther, Klaus-Uwe \& Linda Thornburg. 2011. Emotion and desire in independent complement clauses. A case study from German. In Mario Brdar, Stefan Gries \& Milena Žic Fuchs (eds.), Cognitive linguistics. Convergence and expansion, 87-114. Amsterdam: John Benjamins.

Schlobinski, Peter. N.d. The function of non-embedded dass-clauses in therapeutic discourse. Manuscript.

Traugott, Elizabeth. 1992. Syntax. In Richard Hogg (ed.), The Cambridge history of the English language. Volume 1: The beginnings to 1066, 168-289. Cambridge: Cambridge University Press.

Van der Auwera, Johan \& Vladimir Plungian. 1998. Modality’s semantic map. Linguistic Typology 2. 79-124.

van der Horst, Joop. 1984. Over vorm en inhoud van bijzinnen. In Dik Bakker (ed.), Vorm en funktie in tekst en taal, 154-179. Leiden: Brill.

Van linden, An. 2012. Modal adjectives: English deontic and evaluative constructions in diachrony and synchrony. Berlin: Mouton de Gruyter. 
Van linden, An \& Jean-Christophe Verstraete. 2011. Revisiting deontic modality and related categories. A conceptual map based on the study of English modal adjectives. Journal of Pragmatics 43. 150-163.

Verhagen, Arie. 2005. Constructions of intersubjectivity. Oxford: Oxford University Press.

Verstraete, Jean-Christophe. 2005a. Two types of coordination in clause combining. Lingua 115. 611-626.

Verstraete, Jean-Christophe. 2005b. Scalar quantity implicatures and the interpretation of modality: Problems in the deontic domain. Journal of Pragmatics 37. 1401-1418.

Verstraete, Jean-Christophe. 2007. Rethinking the coordinate-subordinate dichotomy. Interpersonal grammar and the analysis of adverbial clauses in English. Berlin: Mouton de Gruyter. 


\begin{tabular}{|c|l|l|}
\hline Meaning & \multicolumn{2}{|c|}{ Form } \\
\hline \multirow{2}{*}{ Long-range wishes } & \multirow{2}{|c|}{$\begin{array}{l}\text { Modal verbs: mogen, kunnen } \\
\text { Conjunction: dat }\end{array}$} & (Particles: nog, maar) \\
Short-range wishes & Verb: final & Particles: maar \\
& & (Modal verbs: mogen, kunnen) \\
\hline
\end{tabular}

Table 1: Uncontrolled deontic insubordination 


\begin{tabular}{|c|c|c|c|c|}
\hline \multicolumn{2}{|c|}{ Meaning } & \multicolumn{3}{|c|}{ Form } \\
\hline \multicolumn{2}{|c|}{ Strong: Prohibition } & \multirow{5}{*}{$\begin{array}{l}\text { Conjunction: dat } \\
\text { Verb: final }\end{array}$} & \multicolumn{2}{|c|}{$\begin{array}{l}\text { Negative polarity } \\
\text { (Double complementation) } \\
\text { (Particles: maar) }\end{array}$} \\
\hline \multirow{4}{*}{ Weak } & Advice & & \multirow{4}{*}{$\begin{array}{l}\text { Affirmative } \\
\text { polarity }\end{array}$} & Particles: misschien and/or eens \\
\hline & Permission & & & Particles: gerust, maar \\
\hline & Indifference & & & Particles: maar \\
\hline & Challenge & & & Particles: maar and eens \\
\hline
\end{tabular}

Table 2: Controlled deontic insubordination 


\begin{tabular}{|c|c|c|}
\hline Meaning & \multicolumn{2}{|l|}{ Form } \\
\hline Unexpected & \multirow[b]{2}{*}{$\begin{array}{l}\text { Conjunction: dat } \\
\text { Verb: final }\end{array}$} & Scalar expressions \\
\hline Expected and negative & & $\begin{array}{l}\text { Particles: repetition \& continuity: } \\
\text { weer, altijd } \\
\text { Modal verbs: necessity: moeten }\end{array}$ \\
\hline
\end{tabular}

Table 3: Evaluative insubordination 


\begin{tabular}{|c|c|c|c|}
\hline \multicolumn{4}{|c|}{ Complementizer dat + verb-final word order } \\
\hline \multicolumn{3}{|c|}{ Meaning } & Formal marking \\
\hline \multirow{4}{*}{ Deontic } & \multirow{2}{*}{ Uncontrolled } & Long-range & $\begin{array}{l}\text { Modals of potentiality: mogen, kunnen } \\
\text { (Particles: nog, maar) }\end{array}$ \\
\hline & & Short-range & $\begin{array}{l}\text { Particles: maar } \\
\text { (Modals of potentiality: mogen, kunnen) }\end{array}$ \\
\hline & \multirow{2}{*}{ Controlled } & Strong & $\begin{array}{l}\text { Negative polarity } \\
\text { (Double complementation) } \\
\text { (Particles: maar) }\end{array}$ \\
\hline & & Weaker & $\begin{array}{l}\text { Affirmative polarity } \\
\text { Particles: maar, misschien, gerust, eens \& } \\
\text { combinations }\end{array}$ \\
\hline \multirow[b]{2}{*}{ Evaluative } & \multicolumn{2}{|l|}{ Unexpected } & Scalar expressions \\
\hline & \multicolumn{2}{|c|}{ Expected \& negative } & $\begin{array}{l}\text { Particles: repetition \& continuity: weer, altijd } \\
\text { Modal verbs: necessity: moeten }\end{array}$ \\
\hline \multicolumn{3}{|l|}{ Discursive } & (Particle: $z o$ ) \\
\hline
\end{tabular}

Table 4: Types of complement insubordination in Dutch 